\title{
Fiscal Competition and the Composition of Public Expenditure: An Empirical Study
}

\author{
Hannes Winner ${ }^{1}$
}

ABSTRACT

This paper investigates whether fiscal competition affects the structure of public spending, where theory predicts a shift from residential public goods to industrial public goods. We propose an empirical model that specifically accounts for the strategic nature and endogeneity of fiscal competition. Using data for 18 OECD countries and a time period with unprecedented tax competition (1980 to 2000), we find a significant impact of fiscal competition on the composition of public expenditure. This finding is in line with theoretical research, particularly that of Keen and Marchand (1997).

KEY WORDS: $\quad$ fiscal competition, public expenditure, panel data econometrics

JEL Classification: $\mathrm{H} 2 ; \mathrm{H} 4 ; \mathrm{H} 7 ; \mathrm{C} 33$

${ }^{1}$ University of Salzburg and Austrian Institute of Economic Research (WIFO), Austria

\section{Introduction}

Fiscal competition forces governments to lower taxes on mobile bases and to provide public goods at inefficiently low levels. This fundamental result of theoretical work on tax competition dates back to Zodrow and Mieszkowski (1986) and Wilson (1986) (see, e.g., Wilson, 1999, Wilson \& Wildasin, 2004 and Zodrow, 2010 for comprehensive overviews of subsequent contributions). With respect to public goods, Keen and Marchand (1997) have extended this analysis by focusing on the composition of public expenditure. Accordingly, to attract international investors, governments tend to increase public expenditure directly promoting the productivity of mobile capital (industrial public goods, often summarized as public infrastructure). In contrast, expenditure items intended to benefit immobile residents, notably for social security and welfare, are underprovided. Consequently, fiscal competition between countries may induce a systematic shift from residential and redistributive public goods to production-enhancing public goods: "Crudely put,...

-

Corespondence concerning to this article should be addressed to: hannes.winner@sbg.ac.at fiscal competition leads to too many business centres and airports but not enough parks or libraries" (Keen \& Marchand, 1997, p. 35).

Despite its sound theoretical foundation and apart from anecdotal evidence, a systematic empirical analysis on the impact of fiscal competition on the structure of public spending is not yet available. Several authors have highlighted links between globalization and the various dimensions of the welfare state. For instance, Rodrik (1998), analyzing a cross-section of approximately 100 developed and less developed countries, has found that trade openness (i.e., imports plus exports to GDP) is positively associated with all components of public expenditure (see Alesina \& Wacziarg, 1998, for similar evidence). He concluded that "societies seem to demand (and receive) an expanded government role as the price for accepting larger doses of external risk." (Rodrik, 1998, p. 998). Put differently, economic integration increases the risk of losing income, which, in turn, increases the demand for publicly provided goods. However, regressing a country's public expenditure on its capital mobility (trade openness) does not account for the strategic nature of fiscal competition, indicating that Rodrik's approach is less suited to the 

a new port, for example, but a national highway network" (Keen \& Marchand, 1997, p. 34). Furthermore, some expenditure items have both a productive and a consumptive component (see Keen and Marchand, footnote 3). This characteristic becomes important in the empirical assessment of Keen and Marchand.

With regard to these two types of public expenditure, Keen and Marchand have shown a 'compositional inefficiency': '[W]ithin the total of public spending, too much is spent on public inputs and too little on items that directly benefit consumers" (Keen \& Marchand, 1997, p. 46). Intuitively, governments try to attract mobile capital not only by reducing capital tax rates but also by providing additional public inputs. Conversely, residential and redistributive public goods are bound to immobile factors, enabling governments to lower the provision of these expenditure types without running at risk of firm or workforce de-location, which would entail revenue losses (there is a considerable body of theoretical literature suggesting a sound confirmation of the result from Keen and Marchand concerning social and welfare expenditure; see Cremer, et. al., 1997, for an overview). Furthermore, a unilateral change in the expenditure structure from residential to production-enhancing public spending creates a capital inflow and (by assumption) a corresponding capital outflow from other countries. This result, in turn, induces three types of externalities on other countries: (i) a decrease of tax revenue from mobile capital (which is in line with Zodrow \& Mieszkowski, 1986); (ii) falling rents, which lower the revenue of land taxes; and (iii) a decline of (gross and net) wage rates and labor supply with corresponding revenue losses from both labor and land taxation. Keen and Marchand demonstrate that under certain assumptions, each of these externalities is negative. Therefore, the compositional effect is associated with a welfare loss in other countries (Matsumoto, 2000 has demonstrated that this result does not hold if residents are mobile).

\section{Empirical Analysis}

We test the finding by Keen and Marchand of a compositional effect by regressing subgroups of total public expenditure on a variable of fiscal competition. To isolate the impact of fiscal competition, we follow the related empirical literature and control for determinants that are typically used to explain public sector growth.
Regarding fiscal competition, we rely on a time period (1980 to 2000) that is typically viewed as one with increasing tax competition (in the early and mid-1980s) and one where the degree of tax competition was unprecedented (mid- to late 1990s). ${ }^{1}$

Public expenditure: We decompose total government spending according to its main functional categories ('divisions'), as defined by the Systems of National Accounts (SNA93; we do not refer to the current COFOG definitions, as they apply data for a shorter time period dating to 1995; for details, see IMF, 2001, p. 75). We rely on seven divisions as reported in the Government Finance Statistics Yearbook 2001from the IMF: (i) social security and welfare (SOCIAL), which includes, for instance, allowances for families and children and benefits for unemployed or elderly persons but excludes public health expenditure; (ii) housing and community amenities (HOUSING), comprising services on housing development (e.g., regulation of housing standards and purchase of dwelling units for the general public or for people with special needs) and community development (e.g., administration of zoning and land-use laws); (iii) health (HEALTH); (iv) education (EDUC); (v) (general) economic services (ECSERV), which comprise a wide variety of public spending categories, covering expenditure items that benefit mobile (e.g., roads, transport and communication) and immobile factors (such as agriculture, forestry, fishing or mining). To disentangle the effects of fiscal competition, we use two sub-divisions of economic services, namely, (vi) research and development (R\&D) and (vii) transport and communication (TRANSP), which should be more clearly attributable to production-enhancing public inputs. The remainder categories, i.e., expenditure on public order and safety, on defense, on recreation, culture and religion, and on general public services (e.g., executive and legislative organs, administrative and statistical services or foreign economic aid), as well as interest on public debt, are excluded.

As exemplified by Keen and Marchand, (v), (vi) and (vii) should be assigned to industrial public goods and (i) to redistributive public goods. Therefore, we expect a positive impact of fiscal competition on (v), (vi) and (vii) and a negative one on (i). Furthermore, (ii) is bound to the immobile factor of land, leading us to expect a negative relationship between fiscal competition 

Table 1. Relationship between corporate tax reforms (tax rate changes) and tax rate difference to adjacent economies .Probit estimates (weighting scheme is borders).

\begin{tabular}{|c|c|c|c|}
\hline & \multirow{2}{*}{ Overall } & \multicolumn{2}{|c|}{ Corporate tax rate changes } \\
\hline & & Rate reductions & Rate increases \\
\hline Cases & 92 & 68 & 24 \\
\hline \multicolumn{4}{|l|}{ Probit } \\
\hline \multirow{2}{*}{ Lagged tax rate differential to adjacent economies } & $0,029 \#$ & $0,119 * * *$ & $-0,066 * *$ \\
\hline & $(0,019)$ & $(0,032)$ & $(0,026)$ \\
\hline Observations & 219 & 202 & 136 \\
\hline Pseudo $R^{2}$ & 0,272 & 0,352 & 0,424 \\
\hline Country Effects & $44,12 * * *$ & $46,57 * * *$ & $270,00 * * *$ \\
\hline Time Effects & 23,38 & $39,89 * *$ & 11,82 \\
\hline Marginal effect (in\%) & 0,88 \# & $2,31 * * *$ & $-6,62 * *$ \\
\hline
\end{tabular}

Notes: Robust standard errors is parentheses.

*** significant at 1\%, ${ }^{* *}$ significant at 5\%, ${ }^{*}$ significant at 10\%; ${ }^{*}$ significant at $15 \%$.

significant in the case of the overall tax change variable (column 1). Using lags of higher order, we are not able to identify any significant effects. Further, including GDP per capita and the unemployment rate as additional controls leaves the parameter estimates of $\Phi_{t-1}$ almost unchanged. Therefore, the evidence in Table 1 clearly suggests that countries with a positive tax rate differential to adjacent economies are faced with a higher pressure from fiscal competition, which, in turn, increases the likelihood that they will reduce their capital tax rates in subsequent years. These findings are similar to the experience of several recent tax reforms in OECD countries. For instance, in 1994, the German government explicitly referred to international tax competition pressures as it announced a cut of the statutory corporate tax rate from 50 to 45 percent: 'Therefore the most natural way to react to other countries' reduced tax rates was to reduce tax rates as well. Indeed, the official reasons given in the government's comments in the 1994 tax cut pointed to significant tax cuts in competing countries" (Weichenrieder, 1996, p. 53). The same finding holds true for the tax reforms in 1999 (reduction of the corporate tax rate from 45 to 40 percent) and 2001 (from 40 to 25 percent). Commenting on the 2001 reform, Keen (2002, p. 614) summarizes the consequences for low tax countries as follows: 'But even countries that set lower taxes as Germany may now have an incentive to cut further in order to maintain their competitiveness." Similarly, Ganghof (2006), providing comprehensive case studies from tax reforms in seven OECD countries (e.g., Australia, Denmark and Finland) over the last twenty years, concludes that tax rate differentials from other countries represented the main motive to cut capital tax rates (see Andersson, et. al., 1998 for similar conclusions on the Nordic countries; Messere, 1998, for evidence from G7 countries; and Bernardi \& Profeta, 2004, for detailed case studies on seven EU member states). Therefore, we conclude that the (weighted) tax rate differential to adjacent economies is a proper approximation to fiscal competition.

Because jurisdictions are not equally exposed to tax competition, we treat fiscal competition $(\Phi)$ as endogenous; i.e., we use an IV approach (see below for econometric details). The choice of instruments is mainly based on tax competition theory: (i) Capital mobility $(M)$ is an obvious candidate for an instrument, as "'.. the comparison between tax competition and its absence is determined by whether capital is mobile across regions" (Wilson \& Wildasin, 2004, p. 1069). In this case, capital mobility is proxied by trade openness (exports plus imports to GDP) as reported in the Penn World Tables 6.1 (see Heston, Summers \& Aten, 2002). (Alternatively, we use (i) flows 

GDP per capita, dependency and urbanization are taken from the World Development Indicators 2004. Other determinants typically used to explain government growth, notably institutional ones (e.g., the influence of interest groups and bureaucrats or the extent and structure of a country's federalism; see Holsey \& Borcherding, 1997), are not considered in this study, as they are usually time-invariant and thus captured by the country-specific effects (see below).

Specification: We estimate the impact of fiscal competition on the structure of public spending in a fixed effects framework (see Baltagi, 2008, for further details). To isolate the compositional effect, we control for the most important determinants of government expenditure, as outlined above:

$G_{i t}=\beta_{1} \Phi_{i t}+\beta_{2} Y_{i t}+\beta_{3} D_{i t}+\beta_{4} U_{i t}+\alpha_{i}+u_{i t}$,

where $G_{i t}^{d}$ denotes the government expenditure to GDP for country $i$ in year $t$ and the division $d$ (i.e., SOCIAL, HOUSING, HEALTH, EDUC, ECSERV, TRANSP and R\&D, respectively). $\Phi$ is the fiscal competition variable as defined in (1). $Y$ is GDP per capita, $D$ is the dependency ratio, and $U$ is the urbanization rate. $\alpha_{i}$ represents (unobserved) individual effects that do not vary over time, such as political determinants or a country's degree of centralization. $u_{i t}$ is the classical remainder error term.

Estimation: Because $\Phi$ is treated as endogenous in (2), we apply a fixed-effects IV estimation (or FE2SLS) procedure (for details see Baltagi, 2008), where the fitted values $\hat{\Phi}$ of the reduced form (firststage) fixed-effects regression,

$\Phi_{i t}=\delta_{1} M_{i t}+\delta_{2} S_{i t}+\delta_{3} R_{i t}+\delta_{4} E_{i t}+\delta_{5} I_{i t}+$

$+\delta_{6} L_{i t}+\delta_{7} Y_{i t}+\delta_{8} D_{i t}+\delta_{9} U_{i t}+\alpha_{i}+\varepsilon_{i t}$,

are inserted for $\Phi$ in the second-stage regression (2). The standard errors are calculated from the FE2SLS residuals (for details, see Wooldridge, 2010). $M, S, R$, $E, I$, and $S$ are the instruments (i.e., strictly exogenous variables) denoting capital mobility $(M)$, country size $(S)$, the tax structure $(R)$, unemployment $(E)$, inflation $(I)$ and the government ideology index $(L)$.

A crucial factor in IV estimation is the choice of instruments. Empirically, instruments (i) should be relevant, i.e., correlated with the endogenous regressor, and (ii) should be uncorrelated (i.e., orthogonal) with the error term $u_{i t}$. We test (i) with a standard Ftest on the significance of the (excluded) instruments in the first-stage regression (2) and (ii) with the $\mathrm{Wu}$ Hausman $F$-test for endogeneity (see Davidson \& MacKinnon, 1993). From the potential instruments in (3), we choose those that pass (i) and (ii), as well as the Sargan (1958) overidentification test. A remaining problem is heteroskedasdicity. If the error term is heteroskedastic, the standard errors of IV estimation are inconsistent, and the diagnostic tests for endogeneity are invalid. We test the presence of heteroskedasticity with a modified Breusch-Pagan test as developed by Pagan and Hall (1983). In the presence of heteroskedasticity, we apply a (standard) GMM estimator (see Hayashi, 2000, and Wooldridge, 2010, for more details on GMM in the panel data context). It should be emphasized that GMM is efficient even in the presence of heteroskedasticity (of unknown form). Note that the IV estimates are neither biased nor inconsistent. Therefore, we only find small differences between the GMM and IV parameter estimates. In the context of GMM, we test whether the instruments are (jointly) uncorrelated with the error term using the $J$-statistic of Hansen (1982). A rejection of the $J$-test indicates that the instruments (jointly) do not satisfy the orthogonality condition.

\section{Estimation Results}

The data set is unbalanced, where the length of the time series varies slightly across countries (the sample includes Austria, Belgium, Canada, Denmark, Finland, France, Germany, Ireland, Italy, Luxembourg, the Netherlands, Norway, Portugal, Spain, Sweden, Switzerland, UK and USA. The average time period per cross-section is approximately 20). In all regressions, we exclude outliers (single observations with a remainder error in the highest or lowest 1 percentile). In sum, our sample includes approximately 400 observations (see Table A1 for descriptive statistics).

Baseline Results: The estimation results are reported in Table 2. The fit of the regressions is generally well. The F-tests on the excluded instruments suggest that the choice of instruments (i.e., capital mobility, country size, tax structure, unemployment, inflation and government ideology) is valid. The Wu-Hausman 
Table 2. Estimation results - corporate tax rate (weighting scheme is borders)

\begin{tabular}{|c|c|c|c|c|c|c|c|c|}
\hline & \multirow[t]{2}{*}{ TOTAL ${ }^{5}$} & \multirow[t]{2}{*}{ SOCIAL } & \multirow[t]{2}{*}{ HOUSING } & \multirow[t]{2}{*}{ HEALTH } & \multirow[t]{2}{*}{ EDUC } & \multicolumn{3}{|c|}{ Economic Services } \\
\hline & & & & & & Total (ECSERV) $)^{5}$ & $R \& D^{\S}$ & TRANSP \\
\hline \multirow{2}{*}{ Fiscal Competition } & $-0,536 \#$ & $-0,354 * *$ & $-0,117 * *$ & $0,558 * *$ & 0,234 ** & $0,117 * *$ & $0,040 * *$ & $0,126^{* * *}$ \\
\hline & $(0,341)$ & $(0,170)$ & $(0,049)$ & $(0,272)$ & $(0,108)$ & $(0,046)$ & $(0,019)$ & $(0,048)$ \\
\hline \multirow{2}{*}{ GDP per capita } & $-0,160 * *$ & $-0,153$ \# & $-0,072 * * *$ & $0,214 * *$ & 0,046 & $-0,083 * * *$ & $-0,023$ \# & 0,035 \\
\hline & $(0,082)$ & $(0,106)$ & $(0,026)$ & $(0,104)$ & $(0,041)$ & $(0,023)$ & $(0,015)$ & $(0,030)$ \\
\hline \multirow{2}{*}{ Dependency ratio } & $-0,209$ & $-0,094$ & $-0,076$ & $0,607 * *$ & $0,299 * *$ & $0,167 * * *$ & $0,052 * *$ & $0,098 *$ \\
\hline & $(0,343)$ & $(0,187)$ & $(0,056)$ & $(0,307)$ & $(0,121)$ & $(0,050)$ & $(0,022)$ & $(0,052)$ \\
\hline \multirow{2}{*}{ Urbanization } & 0,028 & $0,919 * * *$ & $0,193 * * *$ & $-0,400$ \# & $-0,120$ & $-0,055$ & 0,055 & $-0,235 * *$ \\
\hline & $(0,206)$ & $(0,317)$ & $(0,069)$ & $(0,248)$ & $(0,097)$ & $(0,057)$ & $(0,059)$ & $(0,094)$ \\
\hline Observations & 272 & 228 & 228 & 228 & 228 & 227 & 212 & 221 \\
\hline Countries & 16 & 16 & 16 & 16 & 16 & 16 & 14 & 15 \\
\hline$R^{2}$ & 0,988 & 0,982 & 0,733 & 0,685 & 0,913 & 0,966 & 0,734 & 0,907 \\
\hline Country Effects: & $1704,63 * * *$ & 773,92 & $165,31 * * *$ & 170,82 & $598,27 * * *$ & $651,62 * * *$ & 196,92 & $348,26 * * *$ \\
\hline $\mathrm{F}(\mathrm{DF} 1, \mathrm{DF} 2)$ & (15) & (15) & (15) & (15) & (15) & (15) & (13) & (14) \\
\hline Instrument relevance:a) & $3,76^{* *}$ & $2,23 *$ & $2,05 * *$ & 2,00 \# & $2,19^{\#}$ & $2,59 * *$ & $3,12 * *$ & $3,13^{* *}$ \\
\hline $\mathrm{F}(\mathrm{DF} 1, \mathrm{DF} 2)$ & $(2251)$ & (3 206) & (3 206) & $(2$ 207) & (2 207) & $(4204)$ & $(4$ 191) & (2 201) \\
\hline Endogeneity:b) & - & $7,17 * * *$ & $14,29 * * *$ & $56,97 * * *$ & $33,32 * * *$ & - & - & $17,13 * * *$ \\
\hline F(DF1,DF2) & & (1 207) & $(1207)$ & (1 207) & $(1$ 207) & & & (1 201) \\
\hline Heteroskedasticity:: & $40,04 * * *$ & 23,52 & 16,98 & 3,01 & 3,23 & $47,15^{* * *}$ & $51,92 * * *$ & 23,54 \\
\hline$\chi^{2}(\mathrm{DF})$ & $(22)$ & $(21)$ & (20) & (20) & (20) & $(22)$ & $(20)$ & (19) \\
\hline Overidentification test:d) & 0,20 & 3,38 & 1,84 & 0,17 & 0,73 & 3,82 & 5,36 & 0,93 \\
\hline$\chi^{2}(\mathrm{DF})$ & (1) & $(2)$ & $(2)$ & $(1)$ & $(1)$ & (3) & (3) & $(1)$ \\
\hline
\end{tabular}

Notes: IV-estimates (GMM estimates are indicated with " $§$ "); Standard errors in parentheses; Country effects are not reported. Observations with errors outside the $1 \%$ and $99 \%$ range are excluded. a) F-test on the significance of the instruments; ${ }^{\text {b) }}$ Wu-Hausman F-statistic: $\mathrm{H}_{0}$ : regressor is exogenous (i.e., OLS is consistent and efficient); ${ }^{c}$ Pagan and Hall (1983) test for heteroskedasticity ( $H_{0}$ : no heteroskedasticity); d) Sargan (1958) or - in the case of GMM - Hansen J statistic test on overidentifying restrictions.

*** significant at 1\%, ${ }^{* *}$ significant at 5\%, * significant at 10\%, ${ }^{*}$ significant at $15 \%$.

$F$-statistics for endogeneity are significant throughout, which allows us definitively to reject the null that OLS on (2) is consistent. This conclusion justifies our IV approach. The Sargan- or (in the case of GMM) Hansen-statistics are insignificant in all cases, indicating that the overidentifying restrictions are valid (see the bottom line of Table 2).

Before discussing the compositional effect of fiscal competition, we briefly examine the impact of fiscal competition on total public spending (indicated by TOTAL in column 1 of Table 2). Most importantly, the coefficient on $\Phi$ is negative (at a significance level of 15 percent), suggesting a negative relationship between fiscal competition and the size of the public sector. This finding appears to confirm standard reasoning on tax competition, as advanced by Zodrow and Mieszkowski (1986) among others. The control variables are insignificant for dependency and urbanization and significantly negative for GDP per capita, which is in line with previous evidence from crosssectional studies (see, e.g., Alesina \& Wacziarg, 1998; Ram, 1987; Rodrik, 1998). 
The results for the compositional effect of fiscal competition are reported in the remaining columns of Table 2. Basically, we are able to confirm the hypothesis from Keen and Marchand of a compositional effect. First, fiscal competition exerts a significantly negative impact on expenditure for social security and welfare (SOCIAL) and for housing and community amenities (HOUSING). Second, we obtain significantly positive parameter estimates for general economic services (ECSERV) and the two sub-divisions R\&D and TRANSP (last two columns of Table 2). Third, fiscal competition is positively related to EDUC and HEALTH, indicating that both expenditure items serve as production-enhancing public services in our sample.

With regard to the control variables, the signs of the estimated parameters are almost as expected. GDP per capita tends to be negatively associated with economic services (ECSERV and TRANSP) and HOUSING and is positively related to health expenditure. The dependency ratio is significantly positive for EDUC and HEALTH, suggesting that a larger share of older and younger people increases public spending on these expenditure items. Furthermore, and in accordance with previous studies, the dependency ratio reveals a positive impact on economic services (see Sanz \& Velásquez, 2002). Finally, the urbanization rate is significant in four out of seven regressions, where we obtain positive estimates for SOCIAL and HOUSING and negative ones for TRANSP and HEALTH (with respect to health expenditure, empirical estimates from existing studies suggest a range from 0.1 to 1.3 for GDP, from -0.1 to 0.2 for the dependency ratio and from -0.2 to 0.3 for the urbanization rate; see Gerdtham \& Jönnson, 2000, p. 28, Table 3); the difference from our estimates may be explained by divergent specifications (for instance, health-related studies typically include such variables as the number of physicians or cost-related factors).

Robustness: To assess the sensitivity of our results, we undertake several robustness checks by changing (i) the empirical specification, (ii) the definition of tax competition, (iii) the coverage of the sample, and (iv) the measurement of the capital tax burden $\tau$. The results are summarized in Tables 3 and 4, where we only report the parameters of interest, i.e., the influence of fiscal competition on public expenditure items.

Regarding the empirical specification, we first run a reduced-form between regression with trade open- ness instead of the (weighted) tax rate differential as independent variable (see specification \#1 in Table 3 ). This specification exploits information from the crosscountry dimension of the data and thus is similar to Rodrik's (1998) study. In accordance with Rodrik (1998), we observe a positive relationship between trade openness and all expenditure items with the exceptions of HEALTH and SOCIAL. Because the sample size in these regressions is small, i.e., 16 observations, one should interpret these results very cautiously; however, using data from 115 economies over the period 1970 to 1999 (available from IMF Government Finance Statistics Yearbook 2001, Penn World Tables 6.1 and World Development Indicators 2004), we come to similar conclusions with respect to the impact of openness on total government expenditure and its sub-components. Most importantly, the between estimate for openness is 0.067 (s.e.: 0.022) in TOTAL, -0.009 (0.009) in SOCIAL, and 0.004 (0.001) in HOUSING. For health expenditure, we now obtain a significantly positive estimate (0.006; s.e.: 0.003) in the large sample. However, if trade openness is correlated with the error term (as is demonstrated below; see specification \#6) the impact of the openness variable cannot be consistently estimated by the cross-sectional between regression. Second, to guard against a potential endogeneity problem in (2), we treat the control variables as predetermined (see specification \#2). As shown in Table 3, we nearly find the same parameter estimates shown in Table 2, implying that we do not have serious endogeneity problems with respect to the control variables. Third, in \#3 we follow Hayashi and Boadway (2001) and use the lagged tax rate differential to adjacent economies instead of the contemporaneous (weighted) tax rate differential. We generally obtain much lower parameter estimates as in Table 2 and significant ones only in the case of HOUSING, EDUC, ECSERV and TRANSP. Regarding these regressions, we come to the same conclusions as in Table 2; i.e., we find a negative parameter estimate for HOUSING and positive ones for EDUC, ECSERV and TRANSP. Combining the specifications in \#2 and \#3 does not change this outcome substantially (see \#4 in Table 3). Again, the associated parameter estimates are much lower as in Table 2. This finding, together with a lower $R^{2}$ (not reported in Table 3 ) in all regressions, indicates that the parameter estimates in $\# 3$ and \#4 are downward-biased. Fourth, we re-define the de- 
Table 3 Robustness with respect to alternative specifications and alternative definitions of fiscal competition

\begin{tabular}{|c|c|c|c|c|c|c|c|c|c|}
\hline & & & & & & dependen & t variable & & \\
\hline & & TOTAL & SOCIAL & HOUSING & HEALTH & EDUC & Econ & nomic Serv & rices \\
\hline & & & & & & & Total (ECSERV) & $R \& D$ & TRANSP \\
\hline Point & th estimates from Table 1 & $\begin{array}{l}-0,536^{\#} \\
(0,341)\end{array}$ & $\begin{array}{l}-0,354^{* *} \\
(0,170)\end{array}$ & $\begin{array}{l}-0,117 * * \\
(0,049)\end{array}$ & $\begin{array}{l}0,558 * * \\
(0,272)\end{array}$ & $\begin{array}{l}0,234^{* *} \\
(0,108)\end{array}$ & $\begin{array}{l}0,117^{* *} \\
(0,046)\end{array}$ & $\begin{array}{l}0,040 * * \\
(0,019)\end{array}$ & $\begin{array}{l}0,126^{* * *} \\
(0,048)\end{array}$ \\
\hline Spec & cification & & & & & & & & \\
\hline (1) & $\begin{array}{l}\text { Reduced form with trade } \\
\text { openness - between regres- } \\
\text { sion }\end{array}$ & $\begin{array}{l}0,151 * \\
(0,081)\end{array}$ & $\begin{array}{l}0,047 \\
(0,039)\end{array}$ & $\begin{array}{l}0,012^{* *} \\
(0,005)\end{array}$ & $\begin{array}{l}-0,003 \\
(0,027)\end{array}$ & $\begin{array}{l}0,050^{* * *} \\
(0,015)\end{array}$ & $\begin{array}{l}0,045^{* * *} \\
(0,013)\end{array}$ & $\begin{array}{l}0,007^{* *} \\
(0,002)\end{array}$ & $\begin{array}{l}0,020 * * \\
(0,008)\end{array}$ \\
\hline (2) & Controls predetermineda) & $\begin{array}{l}-0,719 * \\
(0,370)\end{array}$ & $\begin{array}{l}-0,369 * * \\
(0,187)\end{array}$ & $\begin{array}{l}-0,110^{* * *} \\
(0,039)\end{array}$ & $\begin{array}{l}0,519 * * \\
(0,261)\end{array}$ & $\begin{array}{l}0,191 * * \\
(0,080)\end{array}$ & $\begin{array}{l}0,131 * * * \\
(0,038)\end{array}$ & $\begin{array}{l}0,065^{* * *} \\
(0,020)\end{array}$ & $\begin{array}{l}0,097^{* *} \\
(0,040)\end{array}$ \\
\hline (3) & $\begin{array}{l}\text { Lagged tax rate difference to } \\
\text { adjacent economies instead of } \\
\text { IV estimation }\end{array}$ & $\begin{array}{l}0,041 \\
(0,042)\end{array}$ & $\begin{array}{l}0,006 \\
(0,026)\end{array}$ & $\begin{array}{l}-0,014 * * \\
(0,007)\end{array}$ & $\begin{array}{l}0,001 \\
(0,012)\end{array}$ & $\begin{array}{l}0,009 \# \\
(0,006)\end{array}$ & $\begin{array}{c}0,023^{\#} \\
(0,016)\end{array}$ & $\begin{array}{l}0,002 \\
(0,004)\end{array}$ & $\begin{array}{l}0,019 * * * \\
(0,005)\end{array}$ \\
\hline (4) & $\begin{array}{l}(3)+(2) \text { : Lagged tax rate dif- } \\
\text { ference plus predetermined } \\
\text { controls }\end{array}$ & $\begin{array}{l}0,027 \\
(0,042)\end{array}$ & $\begin{array}{l}-0,005 \\
(0,026)\end{array}$ & $\begin{array}{l}-0,016 * * \\
(0,007)\end{array}$ & $\begin{array}{l}0,001 \\
(0,012)\end{array}$ & $\begin{array}{l}0,009^{\#} \\
(0,006)\end{array}$ & $\begin{array}{l}0,021 \\
(0,016)\end{array}$ & $\begin{array}{l}0,002 \\
(0,004)\end{array}$ & $\begin{array}{l}0,019 * * * \\
(0,005)\end{array}$ \\
\hline (5) & $\begin{array}{l}\text { Dependent variable: sub- } \\
\text { components to total expendi- } \\
\text { ture instead of GDP }\end{array}$ & - & $\begin{array}{l}-0,396 * \\
(0,214)\end{array}$ & $\begin{array}{l}-0,158 * * \\
(0,063)\end{array}$ & $\begin{array}{l}0,691 * * \\
(0,321)\end{array}$ & $\begin{array}{l}0,247^{* *} \\
(0,127)\end{array}$ & $\begin{array}{r}0,391 * \\
(0,214)\end{array}$ & $\begin{array}{l}0,124^{* *} \\
(0,051)\end{array}$ & $\begin{array}{l}0,356^{* *} \\
(0,148)\end{array}$ \\
\hline Taxc & competition measure & & & & & & & & \\
\hline (6) & $\begin{array}{l}\text { IV regression with trade open- } \\
\text { ness instead of (weighted) tax } \\
\text { rate differential }\end{array}$ & $\begin{array}{l}-0,344 * * * \\
(0,030)\end{array}$ & $\begin{array}{l}-0,206^{* * *} \\
(0,035)\end{array}$ & $\begin{array}{l}-0,049 * * * \\
(0,010)\end{array}$ & $\begin{array}{l}0,262 * \\
(0,157)\end{array}$ & $\begin{array}{l}0,105 \\
(0,125)\end{array}$ & $\begin{array}{l}0,084 * \\
(0,046)\end{array}$ & $\begin{array}{l}0,014 \\
(0,017)\end{array}$ & $\begin{array}{c}0,087^{\#} \\
(0,058)\end{array}$ \\
\hline (7) & $\begin{array}{l}\text { Difference to minimum tax } \\
\text { country rather than to weighted } \\
\text { tax rate of adjacent economies }{ }^{\text {a) }}\end{array}$ & $\begin{array}{l}-0,672 * \\
(0,389)\end{array}$ & $\begin{array}{l}-0,435^{* * *} \\
(0,153)\end{array}$ & $\begin{array}{l}-0,089 * * \\
(0,040)\end{array}$ & $\begin{array}{l}0,223 * * \\
(0,095)\end{array}$ & $\begin{array}{l}0,075 * * \\
(0,040)\end{array}$ & $\begin{array}{l}0,105^{* * *} \\
(0,034)\end{array}$ & $\begin{array}{l}0,032^{* *} \\
(0,017)\end{array}$ & $\begin{array}{l}0,081 * * * \\
(0,030)\end{array}$ \\
\hline (8) & $\begin{array}{l}\text { Distance rather than border as } \\
\text { weighting scheme }^{\text {a) }}\end{array}$ & $\begin{array}{l}-0,397^{* * *} \\
(0,151)\end{array}$ & $\begin{array}{l}-0,327 * * * \\
(0,067)\end{array}$ & $\begin{array}{l}-0,046^{* * *} \\
(0,012)\end{array}$ & $\begin{array}{l}0,285^{* * *} \\
(0,084)\end{array}$ & $\begin{array}{l}0,119^{* * *} \\
(0,038)\end{array}$ & $\begin{array}{l}0,088 * * * \\
(0,030)\end{array}$ & $\begin{array}{l}0,044^{* *} \\
(0,020)\end{array}$ & $\begin{array}{l}0,042^{* * *} \\
(0,009)\end{array}$ \\
\hline Samp & iple & & & & & & & & \\
\hline (9.1) & Europe ${ }^{a)}$ & $\begin{array}{l}-0,460^{\#} \\
(0,294)\end{array}$ & $\begin{array}{l}-0,442 * * \\
(0,214)\end{array}$ & $\begin{array}{l}-0,087^{* * *} \\
(0,030)\end{array}$ & $\begin{array}{l}0,364^{* *} \\
(0,162)\end{array}$ & $\begin{array}{l}0,142 * * \\
(0,062)\end{array}$ & $\begin{array}{l}0,122^{* *} \\
(0,061)\end{array}$ & $\begin{array}{r}0,027 \\
(0,027)\end{array}$ & $\begin{array}{l}0,098^{* * *} \\
(0,037)\end{array}$ \\
\hline (9.2) & US-Canada & $\begin{array}{l}-0,033 \\
(0,082)\end{array}$ & $\begin{array}{c}0,033 \# \\
(0,019)\end{array}$ & $\begin{array}{c}0,001 \\
(0,003)\end{array}$ & $\begin{array}{l}0,031 \text { *** } \\
(0,009)\end{array}$ & $\begin{array}{c}0,004 \\
(0,003)\end{array}$ & $\begin{array}{l}-0,017 \\
(0,036)\end{array}$ & $\begin{array}{l}0,0003 \# \\
(0,0002)\end{array}$ & $\begin{array}{c}0,005^{\#} \\
(0,003)\end{array}$ \\
\hline
\end{tabular}

Notes: Standard errors in parentheses. a) GMM estimates in italics. ${ }^{* * *}$ significant at $1 \%,{ }^{* *}$ significant at $5 \%,{ }^{*}$ significant at $10 \%$, \# significant at $15 \%$. 
pendent variables by relating the sub-components of public spending to total public expenditure rather than to GDP (\#5). In this case, the estimated parameters are more pronounced than in the baseline case (Table 2), but our conclusions regarding the structure of public spending remain unchanged. This finding does not come as a surprise, given a correlation coefficient between the total expenditure and GDP-based figures of approximately 0.85 .

In $\# 6$ to $\# 8$, we apply alternative tax competition measures instead of the (weighted) tax rate difference to neighboring economies, as defined in (1). First, we estimate \#1 again but treat trade openness as endogenous \#6. In contrast to \#1, fiscal competition exhibits a negative impact on total, social and housing expenditure. This finding, together with significant Wu-Hausman statistics in all regressions (not reported in the Table), allows us to conclude that the point estimates in \#1 are obviously biased. Conversely, the point estimates from $\# 6$ are much lower as those in Table 2 (and insignificant for EDUC and R\&D), which may indicate an omitted variable bias because these regressions fail to capture the strategic nature of fiscal competition. Second, we consider the tax rate difference to a 'tax haven' (\#7), i.e., the country with the lowest corporate tax rate in the sample. The idea behind this re-definition is the observation that countries adjust their corporate tax rates to the tax setting behavior of tax havens, which may be justified by some anecdotal evidence (adjustments to the Irish corporate tax rate may provide a familiar example). Apart from slightly lower point estimates compared to the ones in Table 2, this change tends to have a minor impact on the parameters of interest. Third, we employ distance, rather than geographical neighborhood, as a weighting scheme (\#8). In this case, the typical off-diagonal element of $\mathbf{W}$ is given by $\omega_{i j}=\frac{1}{d_{i j}} / \sum_{j=1}^{J} \frac{1}{d_{i j}}, i \neq j$ and $\omega_{i i}=0 . d_{i j}$ measures the distance between capitals of countries $i$ and $j$ in miles. Specifically,

$d_{i j}=r \cdot \arccos \left[\sin \left(\varphi_{i}\right) \cdot \sin \left(\varphi_{j}\right)+\right.$ $\left.+\cos \left(\varphi_{i}\right) \cdot \cos \left(\varphi_{j}\right) \cdot \cos \left(\lambda_{j}-\lambda_{i}\right)\right]$,

with $r$ as the earth's radius in miles, $\varphi_{i}$ and $\varphi_{j}$ are radian measures of the parallel of latitude of the two countries' capitals, and $\lambda_{j-} \lambda_{i}$ is the radian measure of the difference in meridians of the two countries' capitals.
In contrast to border weights, this weighting scheme allows for fiscal competition between all countries in the sample, even though it gives more weight to the more adjacent economies. Obviously, we obtain similar parameter estimates as in Table 2, indicating that our conclusions with respect to the impact of fiscal competition on the composition of public spending appears to be robust to the concept of adjacency.

We also estimate two separate set of regressions for the European (\#9.1) and the US-Canadian case (\#9.2). For the European countries, we find similar parameter estimates as in Table 2, with the exception that the parameter estimate for TRANSP is now insignificant. In the US-Canada case, we obtain significant effects for TRANSP, R\&D and HEALTH. However, given the small sample size (19 observations), one should interpret these results cautiously.

Finally, it might be argued that our findings are driven by the definition of the capital tax burden $\tau$. For instance, it is well-known that countries compete not only with statutory tax rates but also with ingredients of the tax base, such as depreciation allowances or tax credits, among others. Therefore, we re-estimate our model, applying (i) effective marginal tax rates (EMTR), (ii) effective average tax rates (EATR), and (iii) average effective tax rates (AETR) instead of statutory corporate tax rates. EMTR and EATR represent forward-looking measures of capital tax burden and are widely used to analyze the incentive effects of taxation. The data are published in Devereux, Griffith \& Klemm (2002), covering 18 countries (13 EU member states, excluding Denmark and Luxembourg plus Australia, Canada, Japan, Switzerland and the United States) and the time period 1979 to 2003. EMTR are based on the calculation of a firm's cost of capital for a hypothetical investment project (see King and Fullerton, 1984). EATR are the respective average tax rates on a firm's total profits revealing the tax burden on economic rents (e.g., Devereux and Griffith, 2003). In contrast, AETR on capital represent a backwardlooking measure of the capital tax burden and are defined as the ratio of the actual revenue of capital taxes (including corporate income taxes) and the relevant tax base, i.e., profits and capital gains of private and incorporated firms (see Mendoza, Razin \& Tesar, 1994; to calculate AETR, we use the modifications proposed by Carey \& Rabesona, 2002. Further details are available from the author upon request.) 
Table 4. Robustness with respect to alternative definitions of capital tax burden and distance as weighting scheme

\begin{tabular}{|c|c|c|c|c|c|c|c|c|}
\hline & \multirow[t]{2}{*}{ TOTAL } & \multirow[t]{2}{*}{ SOCIAL } & \multirow[t]{2}{*}{ HOUSING } & \multirow[t]{2}{*}{ HEALTH } & \multirow[t]{2}{*}{ EDUC } & \multicolumn{3}{|c|}{ Economic Services } \\
\hline & & & & & & Total (ECSERV) & $R \& D$ & TRANSP \\
\hline \multicolumn{9}{|c|}{ Weighting scheme is borders } \\
\hline \multirow{2}{*}{ CORPTR $^{\mathrm{a})}$} & $-0,536 \#$ & $-0,354 * *$ & $-0,117 * *$ & $0,558^{* *}$ & 0,234 ** & $0,117^{* *}$ & $0,040^{* *}$ & $0,126 * * *$ \\
\hline & $(0,341)$ & $(0,170)$ & $(0,049)$ & $(0,272)$ & $(0,108)$ & $(0,046)$ & $(0,019)$ & $(0,048)$ \\
\hline \multirow{2}{*}{ EMTR } & $-0,601 * *$ & $-0,270 * *$ & $-0,111 * *$ & $0,266 * * *$ & $0,056 * *$ & $0,093 * *$ & $0,043 * *$ & $0,098 * *$ \\
\hline & $(0,267)$ & $(0,113)$ & $(0,052)$ & $(0,088)$ & $(0,023)$ & $(0,039)$ & $(0,019)$ & $(0,039)$ \\
\hline \multirow{2}{*}{ EATR } & $-0,600 * *$ & $-0,356$ * & $-0,119 * * *$ & $0,351 * * *$ & $0,160^{* * *}$ & $0,104 *$ & $0,086^{\#}$ & $0,097^{* * *}$ \\
\hline & $(0,258)$ & $(0,191)$ & $(0,046)$ & $(0,112)$ & $(0,046)$ & $(0,060)$ & $(0,060)$ & $(0,034)$ \\
\hline \multirow{2}{*}{ AETR } & $-0,562 * * *$ & $-0,421 * * *$ & $-0,054 * *$ & $0,080 * *$ & 0,054 *** & $0,105 * * *$ & 0,049 * & 0,034 * \\
\hline & $(0,190)$ & $(0,160)$ & $(0,024)$ & $(0,039)$ & $(0,017)$ & $(0,034)$ & $(0,025)$ & $(0,019)$ \\
\hline \multicolumn{9}{|c|}{ Weighting scheme is distance } \\
\hline \multirow{2}{*}{ CORPTR $^{\mathrm{a})}$} & $-0,397 * * *$ & $-0,327^{* * *}$ & $-0,046^{* * *}$ & $0,285 * * *$ & $0,119 * * *$ & $0,088 * * *$ & $0,044 * *$ & $0,042^{* * *}$ \\
\hline & $(0,151)$ & $(0,067)$ & $(0,012)$ & $(0,084)$ & $(0,038)$ & $(0,030)$ & $(0,020)$ & $(0,009)$ \\
\hline \multirow{2}{*}{ EMTR } & $-0,678 * *$ & $-0,342 * *$ & $-0,065 * *$ & $0,186^{* *}$ & $0,064^{* * *}$ & $0,090 * * *$ & $0,056^{* * *}$ & $0,039 * * *$ \\
\hline & $(0,281)$ & $(0,162)$ & $(0,028)$ & $(0,081)$ & $(0,018)$ & $(0,029)$ & $(0,022)$ & $(0,009)$ \\
\hline \multirow{2}{*}{ EATR } & $-0,549 * * *$ & $-0,322 * * *$ & $-0,040^{* * *}$ & $0,112 * * *$ & $0,088 * * *$ & $0,082 * *$ & 0,070 * & $0,123 * *$ \\
\hline & $(0,172)$ & $(0,062)$ & $(0,009)$ & $(0,018)$ & $(0,029)$ & $(0,037)$ & $(0,039)$ & $(0,052)$ \\
\hline \multirow{2}{*}{ AETR } & $-0,281 *$ & $-0,210 * *$ & $-0,149 *$ & $0,071 * *$ & $0,087 * *$ & $0,099 * *$ & $0,055 * * *$ & $0,032 * * *$ \\
\hline & $(0,146)$ & $(0,101)$ & $(0,088)$ & $(0,035)$ & $(0,039)$ & $(0,045)$ & $(0,019)$ & $(0,011)$ \\
\hline
\end{tabular}

Notes: GMM estimates in italics; Standard errors in parentheses. ${ }^{\text {a) }}$ Point estimates and standard errors from Table 1 and Table 2.

${ }^{* * *}$ significant at $1 \%,{ }^{* *}$ significant at $5 \%,{ }^{*}$ significant at $10 \%,{ }^{*}$ significant at $15 \%$.

AETR ... Average effective tax rate (implicit capital tax ratio); CORPTR ... Statutory corporate tax rate; EATR ... Effective average tax rate on corporate profits as reported in Devereux, Griffith and Klemm (2002); EMTR ... Effective marginal tax rate on corporate profits as reported in Devereux, Griffith and Klemm (2002).

The results are reported in Table 4, where the point estimates with border (distance) as weighting scheme are presented in the upper (lower) block. Note that the sample size varies considerably between the tax burden concepts (using border distance as the weighting scheme, we have approximately 350 (440) observations for AETR (where the series date back to the early 1970s), and approximately 230 (230) observations for statutory corporate tax rates, EMTR and EATR). Therefore, the point estimates in Table 4 are not directly comparable to one another.

As shown in Table 4, the EMTR and EATR-based estimates are close to those reported in Table 2 and support the prediction of Keen and Marchand. The similar parameter estimates for EATR and EMTR are not surprising, given a correlation coefficient of 0.856 . The correlation coefficient between the statutory corporate tax rate and EATR (EMTR) amounts to 0.385 (0.219) between AETR and EATR (EMTR) to 0.179 (0.132). For AETR, we almost find lower estimates as in Table 2, but the conclusion with respect to the compositional effect of tax competition remains unchanged. Given the correlation coefficient between statutory corporate tax rates and the AETR of -0.048 , this result is quite remarkable. Using distance instead of border as a weighting scheme (lower block of Table 4), we generally obtain lower point estimates as in Table 2. However, our conclusions regarding the compositional effect of fiscal competition are unaffected. Again, fiscal competition exerts a negative impact on SOCIAL and HOUSING and a positive one on expenditure for education, health and economic services (ECSERV, TRANSP and R\&D). 
The estimation results from Table 4 suggest that it does not make a significant difference which tax burden measure is used to analyze the impact of fiscal competition on the structure of public expenditure. The underlying reason is that the definition of the tax base, which is the main distinction between effective and statutory tax rates, is generally highly persistent and time invariant from a statistical point of view. Using effective tax rates in the fixed-effects first-stage regression removes this information from the sample. Furthermore, if the instruments are valid, the attenuation bias due to measurement errors, i.e., the inappropriate choice of tax burden variables, should not appear. As this is apparently the case in our study (see the test statistics in Table 2), we conclude that the estimation results are relatively insensitive with respect to the choice of the tax burden concept underlying our definition of fiscal competition. This characteristic is an attractive feature of the IV specification.

\section{Conclusions}

This paper examines whether fiscal competition affects the composition of public spending. Theory suggests a shift from residential public goods to industrial public goods (public inputs), where the former benefit immobile residents and the latter benefit mobile production factors (see Keen \& Marchand, 1997). Using data from 18 OECD economies and a time period that is typically associated with strong tax competition (1980 to 2000), we provide supportive evidence for this prediction. In particular, we find a decline of expenditure for social security and welfare and for housing and community amenities and an increase on expenditure for education, health and economic services (and its sub-components transport and communication and R\&D). Empirically, we treat fiscal competition as endogenous and apply an instrumental variable approach. An important feature of this framework is that we observe more or less the same results irrespective of the measurement of capital tax burden. Demonstrating that it does not matter whether statutory or effective (marginal or average) tax rates are used to estimate the effects of fiscal competition on the composition of public expenditure may be viewed as the methodological contribution of this paper.

With respect to public spending on social security and welfare, our finding is at odds with the existing evi- dence of a positive relationship between 'globalization' and this expenditure item (see, Rodrik, 1998, for further reference). Fiscal competition may be regarded as an important outcome of 'globalization', and from this perspective, it is surprising that our finding does not fit the prior research. We have two explanations for this. First, the controversial results may be driven by divergent empirical specifications. In our context, we explicitly consider the spatial nature and the endogeneity of fiscal competition. Because such a consideration has not been applied in the literature, we suspect that the abovementioned studies obtain biased estimates. Second, fiscal competition may, in fact, exert downward pressure on government expenditure, especially for social security items, but this effect may be simply outweighed by other aspects of 'globalization' not considered in this study. For instance, trade liberalization may exert downward pressure on domestic wages and employment, especially for low-skilled workers (see, e.g., Wood, 1995). If governments try to absorb these effects by raising expenditure on social programs, such as unemployment benefits or training subsidies, we would observe an increase in public expenditure that may more than offset the negative impact of fiscal competition. In any case, a definitive answer cannot be given until the interaction between fiscal competition and other aspects of 'globalization' have been explicitly analyzed.

\section{References}

Alesina, A., \& Wacziarg, R. (1998). Openness, country size and government. Journal of Public Economics, 69(3), 305-321.

Altshuler, R., \& Goodspeed, T. J. (2002). Follow the leader? Evidence on European and U.S. tax competition. (Unpublished paper). City University of New York.

Andersson, K., Kanniainen, V., Södersten, J., \& Sørensen, P. B. (1998). Corporate tax policy in the Nordic countries. In P. B. Sørensen (Ed.), Tax Policy in the Nordic Countries. (pp. 72-137). Houndmills: MacMillan.

Armingeon, K., Beyeler, M., \& Menegale, S. (2002). Comparative Political Data Set, 1960-2001. Institute of Political Science, University of Berne.

Baltagi, B. H. (2008). The Econometrics of Panel Data, (4th ed.), Chichester: John Wiley \& Sons.

Bayindir-Upmann, T. (1998). Two games of interjurisdictional competition when local governments 
provide industrial public goods. International Tax and Public Finance, 5(4), 471-487.

Bénassy-Quéré, A., Gobalraja, N., \& Trannoy, A. (2007). Tax and public input competition. Economic Policy, 22, 385-430.

Bernardi, L., \& Profeta, P. (2004). Tax Systems and Tax Reforms in Europe. London and New York, NY: Routledge.

Besley, T., Griffth, R., \& Klemm, A. (2001). Fiscal reaction functions. (Unpublished paper). London School of Economics.

Blomqvist, Å. G., \& Carter, R. A. L. (1997). Is health care really a luxury? Journal of Health Economics, 16(2), 207-229.

Borcherding, T. E. (1985). The causes of government expenditure growth: A survey of US evidence. Journal of Public Economics, 28(3), 359-382.

Brueckner, J. K. (2003). Strategic interaction among governments: An overview of empirical studies. International Regional Science Review, 26(2), 175-188.

Bucovetsky, S., \& Wilson, J. D. (1991). Tax competition with two tax instruments. Regional Science and Urban Economics, 21(3), 333-350.

Carey, D., \& Rabesona, J. (2002). Tax ratios on labor and capital income and on consumption. OECD Economic Studies, 35(2), 129-174.

Cremer, H., Forgeaud, V. Leite-Monteiro, M., Marchand, M., \& Pestieau, P. (1997). Mobility and redistribution: A Survey. Public Finance, 51(3), 325-352.

Davidson, R., \& MacKinnon, J. G. (1993). Estimation and Inference in Econometrics. New York, NY: Oxford University Press.

Devarajan, S., Swaroop, V., \& Zou, H. F. (1996). The composition of public expenditure and economic growth. Journal of Monetary Economics, 37(2), 313-344.

Devereux, M. P., \& Griffith, R. (2003). Evaluating tax policy for location decisions. International Tax and Public Finance, 10(2), 107-126.

Devereux, M. P., Griffith, R., \& Klemm, A. (2002). Corporate income tax reforms and international tax competition. Economic Policy, 17(35), 450-495.

Devereux, M. P., Lockwood, B., \& Redoano, M. (2008). Do countries compete over corporate tax rates. Journal of Public Economics, 92 (5-6), 1210-1235.

Fuest, C. (1995). Interjurisdictional competition and public expenditure: Is tax coordination counterproductive? Finanzarchiv, 52(4), 478-496.
Ganghof, S. (2006). The Politics of Income Taxation. A Comparative Analysis. Colchester: ECPR Press.

Gemmell, N. (1993). The Growth of the Public Sector. Theories and International Evidence. Aldershot: Edward Elgar.

Gerdtham, U-G., \& Jönsson, B. (2000). International Comparisons of Health Expenditure: Theory, Data and Econometric Analysis. In A. J. Culyer and J. P. Newhouse (Eds.), Handbook of Health Economics, (Vol. 1) (11-53). Elsevier Science Publishers.

Gomes, P., \& Pouget, F. (2008). Corporate tax competition and the decline of public investment (European Central Bank Working Paper Series 928). European Central Bank. Retrieved from: http://www.ecb. europa.eu/pub/pdf/scpwps/ecbwp928.pdf

Gordon, R. H. (1986). Taxation of investment and savings in a world economy. American Economic Review, 76(5), 1086-1102.

Hansen, L. (1982). Large sample properties of generalized method of moments estimators. Econometrica, 50(4), 1029-1054.

Hayashi, F. (2000). Econometrics. Princeton and Oxford: Princeton University Press.

Hayashi, M., \& Boadway, R. (2001). An empirical analysis of intergovernmental tax interaction: The case of business income taxes in Canada. Canadian Journal of Economics, 34(2), 481-503.

Heston, A., Summers, R., \& Aten, B. (2002). Penn World Table Version 6.1, Center for International Comparisons of Production, Income and Prices at the University of Pennsylvania.

Holsey, C., \& Borcherding, T. (1996). Why does government's share of national income grow? An assessment of the recent literature on the U.S. experience. In D. C. Mueller (Ed.), Perspectives on Public Choice (562-589).Cambridge: Cambridge University Press.

Hoyt, W. H. (1991). Property taxation, Nash equilibrium, and market power. Journal of Urban Economics, 30(1), 123-131.

IMF (2001). Government Financial Statistics Manual. Washington, DC: International Monetary Fund.

Keen, M. (2002). The German tax reform 2000. International Tax and Public Finance, 9(5), 603-621.

Keen, M., \& Marchand, M. (1997). Fiscal competition and the pattern of public spending. Journal of Public Economics, 66(1), 33-53. 
King, M. A. \& Fullerton, D. (Eds.), (1984), The Taxation of Income from Capital. A Comparative Study of the United States, the United Kingdom, Sweden and West Germany. Chicago, IL: Chicago University Press.

Kneller, R., Bleaney, M., \& Gemmell, N. (1999). Fiscal policy and growth: Evidence from OECD countries. Journal of Public Economics, 74(2), 171-190.

Matsumoto, M. (2000). A note on the composition of public expenditure under capital tax competition. International Tax and Public Finance, 7(6), 691-697.

Mendoza, E. G., Razin, A., \& Tesar, L. L. (1994). Effective tax rates in macroeconomics: Cross country estimates of tax rates on factor income and consumption. Journal of Monetary Economics, 34(3), 297-323.

Messere, K. (Ed.). (1998). The Tax System in Industrialized Countries. Oxford: Oxford University Press.

Oates, W. E. (1985). Searching for Leviathan: An empirical analysis. American Economic Review, 75(4), 748-757.

Pagan, A. R., \& Hall, A. D. (1983). Diagnostic tests as residual analysis. Econometric Reviews, 2(2), 159-218.

Quinn, D. (1997). The correlates of change in international financial regulation. American Political Science Review, 91(3), 531-551.

Ram, R. (1987). Wagner's hypothesis in time-series and cross-section perspectives: Evidence from "real" data for 115 countries. Review of Economics and Statistics, 69(2), 194-204.

Randolph, S., Bogetic, Z., \& Hefley, D. (1996). Determinants of public expenditure on infrastructure (Policy Research Working Paper Series No 1661). The World Bank. Retrieved from: http://econpapers. repec.org/paper/wbkwbrwps/1661.htm

Rodrik, D. (1998). Why do more open economies have bigger governments? Journal Political Economy, 106(5), 997-1032.

Sanz, I., \& Velásquez, V. J. (2002). Determinants of the composition of government expenditure by functions (European Economy Group Working Paper No 13/2002). European Economy Group. Retrieved from: http://www.ucm.es/info/econeuro/ documentos/documentos/dt132002.pdf

Sargan, J. D. (1958). The Estimation of economic relationships using instrumental variables. Econometrica, 26(3), 393-415.
Tanzi, V., \& Schuknecht, L. (2000). Public Spending in the 20th Century. A Global Perspective. Cambridge: Cambridge University Press.

Tavares, J. (2004). Does right or left matter? Cabinetts, credibability and fiscal adjustments. Journal of Public Economics, 88(12), 2447-2468.

Weichenrieder, A. (1996). Fighting international tax avoidance: The case of Germany. Fiscal Studies, 17(1), 37-58.

Wildasin, D. E. (1989). Interjurisdictional capital mobility: Fiscal externality and a corrective subsidy. Journal of Urban Economics, 25(2), 193-212.

Wilson, J. D. (1986). A theory of interregional tax competition. Journal of Urban Economics, 19(3), 296-315.

Wilson, J. D. (1991). Tax competition with interregional differences in factor endowments. Regional Science and Urban Economics, 21(3), 423-452.

Wilson, J. D. (1999). Theories of tax competition. $\mathrm{Na}$ tional Tax Journal, 52(2), 269-304.

Wilson, J. D., \& Wildasin, D. E. (2004). Tax competition: Bane or boon? Journal of Public Economics, 88(69), 1065-1091.

Wood, A. (1995). How trade hurt unskilled workers. Journal of Economic Perspectives, 9(3), 57-80.

Wooldridge, J. M. (2010). Econometric Analysis of Cross Section and Panel Data, (2nd ed.), Cambridge, MA: MIT Press.

Zodrow, G. R. (2010). Capital mobility and capital income taxation. National Tax Journal, 63(4), 865-902.

Zodrow, G. R., \& Mieszkowski, P. (1986). Pigou, Tiebout, property taxation and the underprovision of local public goods. Journal of Urban Economics, 19(3), 356-370.

\section{Endnotes}

1 Although the time period ends in the year 2000 (unfortunately, the IMF has since changed its data classification), the paper continues to be relevant for two reasons. First, the time period used in the paper (1980 to 2000) is typically viewed as one with increasing tax competition (in the early and mid-1980s) and one where tax competition was unprecedented (midto late 1990s). In fact, most tax researchers do not view the early 2000s as the strongest period of tax competition. From this finding, one might expect that the main results of the paper continue to hold 
today. Second, as shown below, the paper contains a potentially important methodological contribution in that it addresses the obvious endogeneity of tax competition explicitly in the empirical analysis. We show that it does not matter whether statutory or effective tax rates are used in empirical tax competition applications. This result appears to contradict a notably influential discussion on the selection of a "suitable" type of tax rate (i.e., statutory versus effective tax rates) when comparing tax burdens at the international level. However, this result is less surprising, as it can be easily explained by the fact that tax base allowances typically do not vary considerably over time, and this variation is eliminated more or less fully by the fixed country effects used in the empirical model below.

\title{
Acknowledgments
}

\author{
I am grateful to Peter Egger, Steffen Ganghof, Andreas \\ Haufler, Michael Pfaffermayr, Gerald Pruckner, Rupert \\ Sausgruber and seminar participants at the European \\ University Institute, the University of Innsbruck and the \\ Vienna University of Business and Economics for helpful \\ comments and suggestions. Major sections of the manu- \\ script were written while the author was a visiting fellow \\ at the European University Institute in Florence. I wish to \\ thank the Institute, especially Helen Wallace and Claudio \\ Radaelli, for providing welcome and support. Financial \\ support from the Austrian Research Fund (Fonds zur \\ Foerderung der wissenschaftlichen Forschung (FWF), \\ grant no. P17028-G05) is gratefully acknowledged.
}




\section{Appendix 1}

Table A1. List of variables and summary statistics

\begin{tabular}{|c|c|c|c|c|c|c|}
\hline Variable & Description & $\begin{array}{l}\text { Observa- } \\
\text { tions }\end{array}$ & Mean & $\begin{array}{l}\text { Standard } \\
\text { deviation }\end{array}$ & Minimum & Maximum \\
\hline \multicolumn{7}{|c|}{ Dependent variables } \\
\hline TOTAL & Total public expenditure to GDP & 454 & 36,88 & 9,55 & 13,75 & 58,71 \\
\hline SOCIAL & Expenditure on social security and welfare to GDP & 391 & 14,31 & 4,74 & 5,36 & 25,92 \\
\hline HOUSING & Exp. on housing and community amenity affairs to GDP & 391 & 0,83 & 0,62 & 0,06 & 4,36 \\
\hline HEALTH & Health expenditure to GDP & 391 & 3,13 & 2,24 & 0,11 & 10,24 \\
\hline EDUC & Expenditure on education to GDP & 391 & 2,96 & 1,96 & 0,18 & 7,93 \\
\hline ECSERV & Expenditure on economic services to GDP & 391 & 4,24 & 2,01 & 1,02 & 10,08 \\
\hline$R \& D$ & Expenditure on research an development to GDP & 391 & 1,87 & 1,26 & 0,25 & 6,87 \\
\hline TRANSP & Expenditure on transport and communication to GDP & 348 & 0,45 & 0,42 & 0,01 & 2,34 \\
\hline \multicolumn{7}{|c|}{ Independent variables } \\
\hline D & Dependency ratio & 533 & 52,65 & 5,77 & 43,76 & 73,58 \\
\hline Y & GDP per capita (at PPP; in 1.000) & 533 & 13,61 & 7,22 & 2,22 & 38,91 \\
\hline$U$ & Urbanization rate & 533 & 74,94 & 11,63 & 44,80 & 97,30 \\
\hline \multicolumn{7}{|c|}{ Instruments } \\
\hline M & Capital mobility (trade openness) & 533 & 65,15 & 45,26 & 11,49 & 246,20 \\
\hline$L$ & Country size (relative labor force) & 533 & 1,00 & 1,60 & 0,01 & 7,51 \\
\hline $\mathrm{R}$ & Tax structure (labor income taxes plus sales taxes to GDP) & 533 & 20,94 & 5,32 & 10,00 & 32,00 \\
\hline E & Unemployment rate & 447 & 7,12 & 4,33 & 0,20 & 24,10 \\
\hline । & Inflation rate & 533 & 5,92 & 4,44 & $-0,71$ & 24,53 \\
\hline \multicolumn{7}{|c|}{ Additional variables, used in the robustness section } \\
\hline CORPTR & Statutory corporate tax rate & 324 & 40,31 & 11,85 & 10,00 & 62,73 \\
\hline AETR & Average effective tax rate for capital & 533 & 30,88 & 14,54 & 7,15 & 85,78 \\
\hline EMTR & Effective marginal tax rate on business profits & 324 & 23,43 & 9,67 & 0,00 & 47,07 \\
\hline EATR & Effective average tax rate on business profits & 324 & 33,61 & 10,51 & 5,50 & 56,37 \\
\hline
\end{tabular}




5

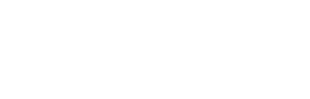

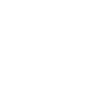

